\title{
Oppressive and liberative: A Zimbabwean woman's reflections on ubuntu
}

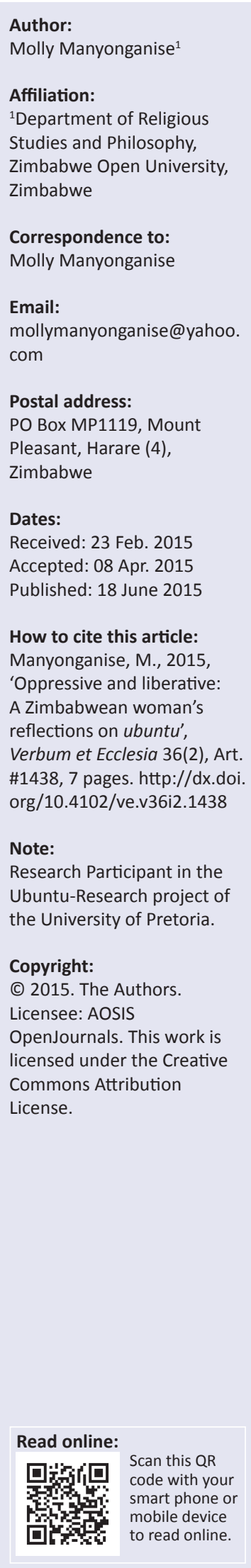

Ubuntu as an African ethic has been embraced in Africa as one that defines an individual's African-ness. Its influence has gone beyond the African borders with other continents pondering how it can be embraced in their contexts. Scholars from Africa and beyond have eulogised the indispensability of $u b u n t u$. However, it is a fact that most academic writings on the concept by various scholars have neglected to look at ubuntu and how it intersects with gender - especially with a particular focus on its ambivalence in the lives of women in Africa. This article, therefore, seeks to make a critical reflection on the ambivalence of the concept focussing mainly on the cultural traditions of the Shona of Zimbabwe from the perspective of a womanist.

\section{Introduction}

In this article, I seek to reflect on $u b u n t u$ using womanist lenses. My justification for using this approach is that the womanist paradigm has become a 'global model that speaks to many' (EllisWilliams 2003:109) African women - be it in Africa or in the diaspora. In this case, the application of the model in the Zimbabwean context is recognition that Zimbabwean women's experiences are historically complex as they are often associated with 'multiple marginalized status of race, class and gender' (Ellis-Williams 2003:110). As such, concepts like $u b u n t u$ cannot be paid tribute to without due analysis on how its deployment affects women. Uchem (2003) has argued that:

Male philosophers often do not address issues of subordination that impinge on women but rather resort to an ethic of 'dignity and role of women', which from her view downplays the humanity of women. (p. 29)

This ethic of dignity and role is the ubuntu ethic.

\section{Defining ubuntu}

Before we proceed any further, we need to understand what we mean by ubuntu; it 'is an African Philosophy that places emphasis on being human through other people' (Mugumbate \& Nyanguru 2013:82). Mbiti (1969:108) puts it well when he says, 'I am because we are, since we are therefore I am' (cf. the Zulu expression 'umuntu ngumuntu ngabantu'). As an African philosophy, ubuntu gives an understanding of us as human beings in relation to the rest of the world. In this case, an action is deemed right or wrong based on how it is related to corporate existence. In ubuntu, corporate existence is a virtue and the human being is the centre of all relationships. To this end, Mugumbate and Nyanguru (2013:83) have described it as Africa's worldview of societal relation and also as a social and humanistic ethic. In the same vein, Mawere (2012) posits that:

Ubuntu is a multi-faceted philosophical system that involves logic, metaphysics, epistemology and ethics; it is a philosophy of life that is concerned with the reinforcement of unity, oneness and solidarity among the Bantu people. (p. 3)

My discussion of ubuntu or hunhu in this presentation is mainly centred on the Shona in general and the Zezuru ethnic group in particular for the mere reason that it is a cultural group that I belong to. The Shona are not a homogeneous group, but are composed of various ethnic groups which at times may have subgroups within them.

The term ubuntu has its Shona equivalent of unhu or hunhu. Hunhu is the ontological, epistemological and moral fountain of African philosophy (Chimuka 2001:29). In the Shona language, the word hunhu connotes being human or humaneness (Mugumbate \& Nyanguru 2013:86). This brings us to another concept of munhu (a person) who is expected to have hunhu (being human). Munhu can mean either an ordinary person or a truly and fully moral person, that is, one who has morally worthy human qualities (Pearce 1990:147). It is possible for the Shona to describe an individual as being not a person, because he or she exhibits negative behaviour ('haasi munhu' because he or she does not have $u n h u$ ) or munhu chaiye, meaning the individual is a 
good person. This is applicable to persons who have chosen to deviate from the societal set norms of what is wrong and what is right. Furthermore, Samkange and Samkange cited in Chimuka (2001:31) limit the applicability of ubuntu or hunhu to Bantu people. Therefore, Chimuka (2001:31) argues that the ethic seems to 'exclude some human beings from vanhu and may easily pass for an essentialist conception of identity'; for example, he writes that (Chimuka 2001):

In as much as foreigners were not cultured in hunhu, they would never be vanhu in the social and moral sense of the term since they would not be socialized in hunhu. (p. 31)

Connotatively, the Shona can use the term munhu to distinguish between a boy and a girl child. After a child is born, people can ask the question 'munhui?' implying the gender of the child. If it is a girl, some may say 'hapana munhu azvarwa' (i.e. 'no human being has been given birth to'); however, when it is a boy they may say 'kwave nemunhu' (i.e. 'we now have a human being'). One finds that, amongst the Shona, if one's wife gives birth to girl children in the initial stages of marriage, they will continue giving birth for the sole reason that they want to have a baby boy who is seen as the 'real' human being. Thus, we find that from birth, the girl child is not valued and is not accommodated in the Shona definition of what a human being is. Whilst the concept of ubuntu has been associated with love, compassion, humility, et cetera, there is its other side which denies women their humanity and this is despite the fact that the philosophy was coined as a way of reclaiming the dignity of the black person from the dehumanising effects of colonialism. In the sections below, I wish to look at this ambivalent nature of $u b u n t u$. I seek to look at how $u b u n t u$ can both be liberative as well as oppressive, especially to women.

\section{The oppressive nature of ubuntu}

We have already seen from the aforementioned discussion that the concept of $u b u n t u$ is classified under African philosophy. As an academic study, the field of African philosophy is dominated by men (Du Toit 2011:111; Mangena 2009:21). Where they have raised a voice, 'many women philosophers and/or ethicists have been portrayed as subordinate figures' (Mangena 2009:20). Thus, most discourses on ubuntu have been done by men who conveniently ignored the implications of $u b u n t u$ on gender. As such, as one reads research focussing on African philosophy, one finds that most discussions on ubuntu glorify the concept as the be-all and end-all of African philosophy. Mugumbate and Nyanguru (2013:88) are of the view that 'the social ethic of $u b u n t u$ has been Africa's largest contribution to the world'. I am therefore persuaded to say that the glorification of the concept without due analysis of its implications for gender is being done mostly by those who are enjoying the patriarchal dividend. I agree with Mangena (2009:20) who argues that the communitarian philosophy of hunhu or ubuntu is full of the whims and caprices of patriarchy. In his analysis, Mangena (2009) claims that:

philosophy in general and ethics in particular are guilty of complicity for their role in gender stereotyping in general and in the subversion of women's values in African academic discourses. (p. 20)
Patriarchy is embedded in a gender ideology which places men at the top and women as their subordinates. According to Hussein (2005:60), the 'African gender ideology is a system of shaping different lives for men and women by placing them in different social positions and patterns of expectations'. He identifies rituals, legends, name-giving ceremonies, oral narratives, proverbs, aphorisms and usages as instruments that have been in the vanguard of mobilising gender ideology. In the following sections, I look at Shona women's negative experiences of ubuntu or hunhu in the various aspects of their lives.

\section{Ubuntu, women and social life}

Within or without the academic discourses, ubuntu or hunhu can be seen as engendering patriarchy; for instance, its metaphysical dimension is linked to the belief in and respect of ancestral spirits who amongst the Shona are mostly related to patrilineal descent. This is the reason why male children are often highly regarded over and above their female counterparts. It is the boy child who ensures that the family lineage is carried forward. According to Chitando and Mateveke (2012:43), 'it is the male child who is treasured as he ensures that the lineage and homestead avoid the greatest existential threat: extinction (dongo)'.

When it comes to decision-making, in most cases women are not consulted and, as a result, their voices are silent. At the traditional dare (court), whether it is a family or community court, a common expression is often uttered: 'vakadzi ngavanyarare' ('women should keep quiet'). As Chimuka (2001:28) alleges, citing Ramose and Samkange, the traditional court was modelled around the ubuntu or hunhu philosophy. At these courts, decisions are made by men, whilst women remain listeners and silent implementers of men's decisions. It is like the biblical woman of 1 Corinthians 14:34-35 who Paul says should not engage in public discourses, but when in public should learn in silence. To this end, Chitando and Mateveke (2012:44) argue that 'Christianity has played a major role in promoting patriarchy and its attendant notions of women's domesticity and decency'. One would then think that within the private domain, women have a say. The media in Zimbabwe today is full of stories of women who are abused physically, sexually and verbally - even within the private spaces of the home. The enactment of the Domestic Violence Act ${ }^{1}$ of 2007 needs to be understood within this context. However, the Shona proverb which says 'chakafukidza dzimba matenga' (implying that the secrets of the home need to remain untold) was mainly meant to silence women from disclosing how they were being treated by their husbands. In such cases, abusive partners would continue with their abusive behaviour realising that the public would never know about it. One would have thought that the instatement of the aforementioned law would be lauded by both men and women as an effort to create peaceful

1.The Domestic Violence Act is an Act of Parliament of the Government of Zimbabwe which was enacted in 2007 as a way of dealing with violence that occurs in the which was enacted in 2007 as a way of dealing with violence that occurs in the
home. Although the Act protects both men and women against violence, there is a general view that women are the major victims of this violence. 
environments within the home. This has not been the case as some feel that the law is empowering women to expose what traditionally would have remained within the confines of the home. Mpofu (2012:198) projects the Domestic Violence Act of 2007 as a statutory instrument which undermines the culture of the Zimbabwean communities, and argues that:

It is nauseating to notice that the marital issues which have always been private matters as enshrined in the Shona proverb 'chakafukidza dzimba matenga' especially marital issues have been pushed into the public horizon. (p. 198)

It is this expected silence from society about their painful experiences which often lead women to suffer in silence. Even after reporting their husbands for abuse to the police, most women withdraw their cases due to societal pressure because a 'real' woman ('mukadzi chaiye') does not do that. This construction of an ideal woman has led many to their death; for example, even after discovering that their husbands are engaging in extra-marital relationships and have contracted HIV, most women continue to sleep with their husbands, making themselves vulnerable to infection in the process. Shona women are taught that at no point should they deny their husbands sex ('murume haanyimwe bonde'). Moreover, their subordinate position does not enable them to demand that thy use protection during sexual intercourse. According to Machingura (2012:51), 'noble women "vakadzi chaivo" - real women are typified as not to be associated with the use of condoms, even in the face of promiscuity'. In this case, Machingura (2012:50) notes that 'the Shona culture and most religions in Zimbabwe like African Traditional Religion and Christianity are the major stumbling blocks in the empowerment of married women on safe sex'. In the event that a woman's husband succumbs to AIDS, society expects the woman not to abandon him but to care for him. Women in Zimbabwe have carried the burden of care for those infected, yet in most cases they find that when they are the ones needing the care, their husbands often neglect them or take them back to their families of birth. Society does not see anything wrong with such an arrangement because it is commonly believed that men are not 'natural' carers.

Women in Zimbabwe have suffered harassment in public places in the name of ubuntu or hunhu. The Shona generally view issues of dress as one area where one's morals can be judged. As such, women who wear mini-skirts are often vilified. Women have been attacked and their mini-skirts torn by men who view them as denigrating African culture. It is difficult to conceive that the one who is putting on a mini-skirt is deemed immoral and yet the men who undress and tear the mini-skirt find it moral to justify such acts. Therefore, we need to question why, in defense of an ethic that encourages love and compassion, men use violence against women. Oppah Muchinguri, the former Minister of Women's Affairs, Gender and Community Development, speaking at a protest march of a woman who had been murdered in her sleep by her husband in May 2014 (i.e. Isabel Masuka), attributed gender-based violence to cultural values created by men who have a powerful position in a patriarchal Zimbabwean society. She argued that it is not easy to shake patriarchy and that men are our problem. They are the ones who define culture, and they bend it when it suits them (Chirumanzu 2014).

In this case, $u b u n t u$ needs to be seen as a creation of men who were determined to regard women as restricted, dominated and marginalised. Samkange and Samkange cited in Pearce (1990:149) posit that a woman occupies an ambiguous place in the moral system, for although she is munhu, she can be beaten as a child. Hence, the domestic and public violence experienced by women in Zimbabwe is embedded in the way culture has defined a woman's place in society.

This is the reason why some proverbs and sayings in Shona are stereotypical in terms of the representation of women; for example, the saying 'mukadzi mutsvuku akasaroya anoba' (i.e. 'a light in complexion woman, if she is not a witch, she is definitely a thief') was meant to warn men to be cautious of beautiful women lest they had other hidden short comings. In such cases, beautiful women would feel indebted to the men who were courageous enough to marry them despite these societal attitudes and would therefore try to prove beyond any reasonable doubt that although they were beautiful, they were neither witches nor thieves. Nothing is said of the men who might have the same complexion. There are other sayings or expressions in Shona that negatively depict women as a social group that are unable to keep secrets. In his poem, Chawanzwa ('What you have heard'), J.C. Kumbirai advises men not to tell women what they have heard:
Chawanzwa usaudze mukadzi

Mukadzi idare rinoti ngwengwengwe

Chaanzwa achiridza kwese
What you have heard never tell a woman

A woman is a sounding metal

What she hears ringing out everywhere. (Fortune n.d.)
In this poem, Kumbirai depicts women as having a weakness in terms of being incapable of keeping secrets. Once they hear something, they go about preaching it everywhere. Thus, Hussein (2005:61) aptly notes that the African oral traditions portray women in general as foolish, weak, jealous, evil, unfaithful, dependent, frivolous and seductive'.

Ubuntu is exclusive. Strict adherence to the concept creates exclusionary identities which are often viewed as 'others' within specific boundaries; for example, married women are often excluded from important decision-making meetings within their husband's families. When they go back to their families of birth, they are told that they cannot make any major decision because they no longer belong there. In this case, these notions of mutorwa ('alien') are a creation of exclusionary identities which often reinforce exclusionary boundaries. More often, women find out that they do not belong to either their families of birth or the families to which they are married. In a market economy like Zimbabwe, we have women who are choosing not to get married. This is not expected in the ubuntu or hunhu philosophy which stipulates marriage for all. Those that do not get married are derided by 
society because a 'real' woman finds respect in motherhood. This kind of attitude removes the power of choice from the woman who may feel obliged to adhere to the expected norms despite them feeling otherwise.

On the other hand, the practice of polygamy in Shona society puts most women in both a subordinate and precarious position. Shona society is traditionally polygamous, and according to Bowan (2013):

Polygamy and patriarchy have long been comfortable bedfellows, and the rights of women have always been subordinated to the larger freedoms enjoyed by men and to the patriarchal perception of the good of the community. (p. 50)

Shona authors who have written stories depicting Shona polygamous families have almost always highlighted how these families were characterised by conflicts, unhappiness and a sense of lack, amongst many other negative things. In the era of HIV and AIDS, women in Zimbabwe have become more vulnerable to the virus. Thus, Bowan (2013:55) argues that 'a woman faces a raft of abuses through the inequalities and vulnerabilities imposed through customary, polygamous marriage'. In most cases, the philosophy of ubuntu or hunhu is invoked in order to silence or wade off resistance from the affected women; for example, the Shona have a proverb which says 'chembere ndeyembwa, yemurume ndibaba vevana' (i.e. 'what grows old is the dog, a man continues to father children'). This justifies the continued marrying of wives by men because the general belief amongst the Shona is that once a woman reaches menopause, they lose interest in sex; therefore, a man is allowed to marry someone much younger to offer him 'much needed' sexual services.

Ubuntu is also discriminatory to those whose actions and behaviour does not quite fit in its tenets; for example, in Zimbabwe, homosexual individuals have been discriminated against on the basis of their sexual orientation. The major argument against these individuals is that they do not conform to the set standards of marriage. Often asked is the question: what kind of behaviour is that? (i.e. 'Hunhuiko ihwohwo?'). In Zimbabwe, these people have been described as being 'worse than pigs and dogs' and have been threatened with death. Yet those calling names and threatening people with death do not seem to have the time to consider whether their actions are consistent with the $u b u n t u$ philosophy. Or is it a question of the powerful imposing what they conceive as unhu on the 'perceived' weak groups in society? This becomes cultural relativism where one group is privileged over the other; in this example, it becomes a case of heterosexual people versus homosexual people. Lesbian people, in this case, are considered more vulnerable because they are women living in a patriarchal society and homosexual in a society that is, to a large extent, antihomosexual. In a study by Aarmo (1999) on homosexuality in Zimbabwe, she discovered that some lesbian people in rural Zimbabwe were thrown out of their parental homes or were sexually abused through organised rape as a means of 'correcting' their sexual orientation. This goes to prove that in a Shona woman's social life, as in other facets of life, ubuntu or hunhu can be very oppressive.

\section{Ubuntu, women and political life}

Politics is one area where the concept of ubuntu or hunhu shows its exclusionary tendencies. I have implied earlier that in Shona traditional society, women are not expected to actively participate in decision-making. In political structures of traditional societies, there was no place for a woman. Thus Ogunsanya (n.d.) points out that 'Africa has culturally been a patriarchal society and leadership the domain of men'. In postindependent Zimbabwe, we have seen a steady rise of women in political office. Despite this increase, female politicians have not been as effective as expected. As such, Ndlovu and Mutale (2013) note that:

Women's increasing presence in governance institutions has generally not had much transformative impact on the subtle patriarchal cultures and practices in Africa. Progression in opening up spaces for women's political participation in Africa has not gone along with the diminishing of patriarchal power structures. (p. 76)

The political violence that Zimbabwean women have historically experienced needs to be located within the framework of trying to sideline women from political participation irrespective of the fact that they constitute more than half of the population. The exclusionary tendencies of ubuntu or hunhu are being witnessed in Zimbabwe's current political environment where women have been told to desist from being ambitious. The former Vice-President, Joice Mujuru, has been presented as one who does not have ubuntu or hunhu because she dared to dream of being the President of the Republic. President Robert Mugabe's statement 'and the person who wants to take over is a woman for that matter' is meant to show that women cannot be leaders of Zimbabwe, yet they constitute more than half of the Zimbabwean population. It seems to suggest that women are not human enough to warrant the highest office in the land. From a gendered perspective, the bastardisation of Mujuru's position has shown that a woman who dreams about becoming the president of Zimbabwe is dangerous to patriarchy and, if dangerous, then they are put in their place. In response to this vilification, supporters of Mujuru went beyond just defending her. They reproduced archival pictures of Mujuru in war regalia holding a gun, thereby masculinising her. They tried to prove that although she is a woman, Mujuru had traversed the social spaces. By participating in the war which traditionally was a preserve of men, Mujuru should be regarded as fit to rule Zimbabwe.

\section{Ubuntu, women and land ownership}

Generally, Zimbabwe has been applauded for its development in education policy with its 1980 independence policy of 'Education for All', thereby placing it on the world's education map. Its labour policies have placed men and women at par (the 'Equal Work for Equal Pay' policy). When one looks at these achievements, they may overlook other critical spheres of life in which women are marginalised. The land reform in Zimbabwe is one area that has remained problematic in Zimbabwe with the majority of women still at 
the margins in terms of land ownership. As Kameri-Mbote (2005-2009:1) rightly notes, 'the ownership of land and associated resources is very much anchored in patriarchy'. In Shona society, women work the land, but do not own it. In cases where women want to farm those crops which are deemed to belong to them (such as groundnuts and round nuts), they would have to access the land through the men. In other words, it is the father, husband or brother of the woman who decides where these have to be planted. In Zimbabwe, even after the land reform that took place between 2000 and 2002, land remains an emotive issue (Mangezvo 2013:83). Very few women benefitted from the programme. The Presidential Land Committee Report cited by Mangezvo (2013:76) indicates that $80 \%$ of women live in the rural areas yet over $80 \%$ ownership of prime agricultural land lies with men. This is indicative of the fact that although Zimbabwe claims to be a modern society, its land reform has largely been informed by cultural values that dictate that women can only access land through a male figure in their lives. To this end, Kameri-Mbote (2005-2009) argues that:

In Africa ... women regardless of their marital status cannot own or inherit land. Women are assumed to be transient within the polity and therefore not strategic as grantees of rights to land which constitutes the core of a community's existence. Besides, there is the perception that women are part of the wealth of the community and cannot therefore be the locus of land 'rights' grants. (p. 6)

Kameri-Mbote (2005-2009) brings into this discourse a critical component that men have used to justify the marginalisation of women in society, that is, the issue of lobola. In Shona society, it is not ubuntu or hunhu for a man to live with a woman as husband and wife without paying lobola to the woman's family. This has been misconstrued to mean the commoditisation of women. In such cases, husbands tend to view their wives as 'purchased goods'. In Zimbabwe today, where women are officially employed, some of them are encountering challenges where their husbands demand that they surrender their salaries at the end of each month. These husbands may be interpreting a woman's professional job as a symbol of the land where women would till and surrender the produce to the men. We see here that the philosophy of ubuntu is being used to curtail the economic freedom of women so that they remain under the control of men.

\section{The liberative nature of ubuntu}

Despite the philosophy of ubuntu being largely oppressive to women, there are other ways in which it can also be empowering. Ubuntu as a concept strengthens women in the home. The common Shona expression 'musha mukadzi' provides women with some spaces within which they can exercise some level of control. This is despite the other views that have projected this expression as a way of domesticating women (Manyonganise 2010:16). According to Van Stam (n.d.), this expression 'indicates the existence of a pivotal role of women as the mothers of communities in ubuntu society'. In this case, Mangena (2009) argues that:

While hunhu or ubuntu promotes masculine values, it also gives women the opportunity to show men that apart from being able to initiate and influence things in the home and in the larger community, women organize and sustain society. (p. 25)

In other Shona sayings and proverbs there is a projection of ways in which women were revered; for example, the proverb 'nhamo inhamo zvayo, amai haroodzwi' implies that one cannot send their mother to be married, especially through betrothment because there is poverty in the family. The other expression which is normally uttered when one is in serious trouble is 'mudzimu waamai wadambura mbereko', implying that the maternal ancestors have chosen not to protect the individual. In this case, children are encouraged to ensure that their mothers are not angry with them so that in the after-life, their mothers can ensure their protection. Thus, when a daughter is getting married, although the father gets the larger amount of the lobola, the mother is entitled to her part. Amongst the Zezuru, the mother receives mapfukudza dumbu (i.e. where the groom pays for his mother-in-law's womb, which was kicked by the bride during pregnancy), mombe yeumai (i.e. the mother's cow) which is meant to thank the mother-in-law for playing her motherly role in bringing up the bride, as well as some groceries. This goes to show that a mother is also revered in Shona society in certain contexts. Women can therefore use this recognition positively to socialise their children in ways that seek to redefine $u b u n t u$ to become a liberative and not an oppressive African ethic.

Furthermore, in times of trouble and when someone is showing their astonishment, the expression 'Mhaiwe' (i.e. 'My mother') is often uttered by both the Shona man and woman. Thus, Mazuru and Nyambi (2012) explain this clearly when they say:

In times of discomfort, children, young and grown, seek solace and comfort in the arms of their mothers and even when they cry, they call out to their mothers, which vindicates the belief that a mother is supreme. This is embodied in the following proverbs: Baba muredzi mwana kuchema anodaidza mai (A father is just a nurse when a child cries it calls out to the mother: Mai musuva usingasehwi mumuto (A mother is like a morsel which needs no dipping into gravy). (p. 599)

The proverb, 'amai vafa, vana vorezviwa nani?' (i.e. 'A mother has died, who will take care of the children?'), shows that women as mothers are regarded highly in Shona society. The philosophy of ubuntu or hunhu encourages children to respect their mothers. However, what seem to be lacking in the Shona conception of ubuntu or hunhu are sayings that encourage husbands to treat their wives with love and respect.

There are yet other proverbs in Shona which point to the importance of women in Shona society. The proverb, 'chembere mukadzi hazvienzani nekurara mugota' (i.e. 'An old woman is a wife, it cannot be compared with one sleeping in the bachelor's room'), was meant to encourage men to get married. It is generally taboo in Shona society for a man to get married to a woman who is older than him. However, this proverb shows that there are instances where this is permissible if the man appears to struggle in terms of finding 
a suitable wife, society could advise him to cast his net wider to include older women. For them it was better to marry an older woman than to continue being a bachelor.

Another proverb, 'nhumbu mukadzi mukuru hairevi chayadya' (i.e. 'A stomach/womb is a mature woman, it does not say what it has eaten'), illustrates that Shona society recognises women's strengths; for example, in this proverb, either the stomach or the womb is likened to a mature woman who is indeed able to keep a secret. This is in stark contrast to the views of J.C. Kumbirai who sees women as noisy bells who reveal everything that has been told to them in confidence.

\section{The future of ubuntu from a womanist perspective}

This reflection is being done within the womanist framework. In this case, African womanism by Alice Walker is utilised in this article. As a theory, womanism was introduced by Alice Walker in 1983 as a reaction to the shortcomings of feminism (Ebunoluwa 2009:229). It has since been adopted by African women theologians as a useful theory in understanding human relationships in religion as it brings out insights about moral life based on ethics supporting justice for women, survival and a productive quality of life. According to Walker quoted by Ellis-Williams (2003:115), 'a womanist is "one" who is committed to the survival and wholeness of entire people, male and female'. Thus, Williams cited in Ellis-Williams (2003:115) argues that womanists not only concern themselves about the liberation of women, but they also struggle along with black men and children for the liberation, survival and positive quality of life for the entire community. As such, womanism presents an alternative for black women by framing their survival in the context of the survival of their community where the fate of women and that of men are inextricably linked. In this case, Chitando (2011:10) sees a womanist as a woman with a holistic approach to the struggles of the community as a whole. What one can say in short is that womanism focusses on the transformative power of individual and communal resistance to the conditions of oppression. In this case, the womanist paradigm becomes relevant in shaping the future of $u b u n t u$ in African communities because of its close affinities with the African ethic. Scholars like Thomas (1997) have tried to equate womanism with ubuntu.

The strength of womanism is on its insistence on women working with men to eradicate the oppression of women. It creates spaces for dialogue between men and women on how to deal with this oppression. According to Collins (2001:11), womanism seemingly supplies a way for black women to address gender oppression without attacking black men. This way is one in which men and women come to realise that men have been enjoying the patriarchal dividend at the expense of the freedom and empowerment of women. In doing so, men have been appealing to the ubuntu or hunhu ethic as the basis of the values that to a large extent have marginalised women. Therefore, men and women need to come to the negotiating table with the common view that $u b u n t u$ or hunhu advantages men more than women and this becomes the major reason why it needs to be interrogated. In this interrogation, both male and female African philosophers need to clearly define women's place and relevance in the ubuntu or hunhu philosophy. Mangena (2009:28) asserts that it is worrying that men are driving the hunhu or $u b u n t u$ initiative and women are passive recipients. Therefore, ubuntu or hunhu needs to be reconstructed so that it ceases to be steeped in the past, especially in gender relations. The ascribing of gender roles can be self-defeating; for example, in a volatile economic environment such as currently prevalent in Zimbabwe, there is no guarantee that the men remain bread winners. It should not become difficult for women who are employed to take care of their families when their husbands are out of work. However, Zimbabwe has witnessed marriages breaking once men become unemployed, and the major reason is steeped in ubuntu or hunhu which characterises the man as the head of the family who should be its sole provider.

Ubuntu or hunhu needs to be liberating and life-giving to women. As such, there is a need to interrogate and challenge those customs, traditions and cultural practices that dehumanise women in the name of ubuntu or hunhu. From Mangena and Chitando's (2011) perspective, ubuntu or hunhu must question:

Men's lifestyles, expensive tastes, militancy, multiple concurrent sexual partnering and other troublesome aspects of masculinity. Men must be challenged to give up dangerous ways of being human, in line with the demands of hunhu or ubuntu. This implies recognizing the humanity of women and giving full attention to their capacities. (p. 242)

This view is supported by Chirongoma, Manda and Myeni (2008:194) who argue that 'since $u b u n t u$ means being human or humanness, then the central ethical value and starting point is dignity, that is, the dignity of persons because they are persons'. In this case, the dignity of women as individuals is of paramount importance. Ubuntu or hunhu cannot continue to be used as a useful tool for the marginalisation of women. Its redemption from this curse is critical if women in Africa are to realise their full humanity. In this process, Dube (2009) argues that:

Botho/Ubuntu/Buthu, as a process of earning respect by first giving it, and gain empowerment by empowering others, would be applied to all problematic relationships. Socially unhealthy relationships that do not empower or respect certain members of society would be reexamined. The concept of community, the Botho/Ubuntu/Buthu paradigm should become the cornerstone for propounding the African philosophy of justice and liberation by constantly revisiting what it means to be community and live in community, what violates community, and how to live in community in the new and hybrid twenty-first century contexts. Being a community is not something set. It is a process that must be continually cultivated by its members. Relationships should be constantly assessed. Any that are oppressive should be reviewed. (p. 202)

Dube's assessment provides the basis for reassessing $u b u n t u$ or hunhu in the interests of gender equality and equity. 


\section{Conclusion}

We can conclude that $u b u n t u$ or hunhu is not a perfect African philosophy although many scholars have presented it as such. From the proverbs and sayings analysed from the Shona in Zimbabwe, the ambivalence of ubuntu or hunhu has been shown. Whilst on the one hand, ubuntu or hunhu is liberative to women, on the other, the discussion has shown that there are elements within the ethic which marginalise and disempower women. Drawing from the womanist approach, the article has advocated for the reconstruction of $u b u n t u$ or hunhu where the position of women is clearly defined so that an ethic that has been applauded for its humane-ness cannot be seen to be gender insensitive. An ubuntu or hunhu ethic that is liberative is one that is life-giving to African women and those beyond African borders.

\section{Acknowledgements Competing interests}

The author declares that she has no financial or personal relationships which may have inappropriately influenced her in writing this article.

\section{References}

Aarmo, M. (1999), 'How homosexuality became "un-African": The case for Zimbabwe', in E. Blackwood \& S.E. Wieringa (Eds.), Female desires: Transgender practices across cultures, Columbia University Press, New York.

Bowan, L., 2013, 'Polygamy and patriarchy: An intimate look at marriage in Ghana through a human rights lens', Contemporary Journal of African Studies 1(2), 45-64.

Chimuka, T.A., 2001, 'Ethics among the Shona', Zambezia XXVII(i), 23-37.

Chirongoma, S., Manda, D.S. \& Myeni, Z., 2008, 'Ubuntu and women's health agency in contemporary South Africa', in S. De Druchy, N. Koopman \& S. Strijbos (eds.), From our side: Emerging perspectives on development and ethics, UNISA Press, Pretoria.

Chirumanzu, G., 2014, 'Men are our problem - Muchinguri', The Zimbabwe Mail, 20 May, n.p.

Chitando, A., 2011, Fictions of gender and the dangers of fiction in Zimbabwean women's writings on HIV and AIDS, Africa Institute for Culture, Dialogue, Peace and Tolerance Studies, Pretoria.

Chitando, E. \& Mateveke, P., 2012, 'Challenging patriarchy and exercising women's agency in Zimbabwean music: Analysing the careers of Chiwoniso Maraire and Olivia Charamba', Muziki: Journal of Music Research in Africa 9(2), 41-52. http:// dx.doi.org/10.1080/18125980.2012.742234
Dube, M., 2009, 'I am because we are: Giving primacy to African indigenous values in HIV and AIDS prevention', in M.F. Murove (ed.), African ethics: An anthology of comparative and applied ethics, University of KwaZulu-Natal Press, KwaZuluof compal.

Du Toit, L., 2011, 'Old wives' tales and philosophical delusions: The problem of women and African philosophy', in G. Walmsley (ed.), African philosophy and the future of Africa, pp. 111-128, The Council for Research in Values and Philosophy, USA.

Ebunoluwa, S.M., 2009, 'Feminism: The quest for an African variant', The Journal of Pan African Studies 3(1), 228-234.

Ellis-Williams, A., 2003, 'Transforming communities: An examination of a womanist paradigm and its universality in human rights', Public Policy Forum 1(2), 109-128.

Fortune, G., n.d., Sfaona traditional poetry, Department of African Languages, University of Rhodesia, Salisbury.

Hussein, J.W., 2005, 'The social and ethno-cultural construction of masculinity and femininity in African proverbs', African Study Monographs 26(2), 59-87.

Kameri-Mbote, P., 2005-2009, 'The land has its owners! Gender issues in land tenure under customary law in Kenya', International Environmental Law Research Centre Working Paper, International Environmental Law Research Centre, Geneva.

Machingura, F., 2012, 'A look at the struggle of Zimbabwean married women regarding safe sex', Africana 6(1), 40-60.

Mangena, F., 2009, 'The search for an African feminist ethic: A Zimbabwean perspective', Journal of International Women's Studies 11(2), 17-30.

Mangena, F. \& Chitando, E., 2011, 'Millennium development goals in Zimbabwe's "decade of crisis"', Journal of Sustainable Development in Africa 13(5), 233-245.

Mangezvo, P.L., 2013, 'Debating the global political agreement and gender equality in Zimbabwe: A critical analysis of women's access to land ownership and political decision-making', Southern Peace Review Journal 2(1), 75-96.

Manyonganise, M., 2010, 'From "safety" zones to public spaces: Women's participation in sport in Zimbabwe', in J. Shehu (ed.), Gender, sport and development in Africa: Cross-cultural perspectives on patterns of representation and marginalisation, $\mathrm{pp}$. 13-26, Codesria, Dakar.

Mawere, M., 2012, 'Buried and forgotten but not dead: Reflection on "ubuntu" in environmental conservation in South-Eastern Zimbabwe', Afro-Asian Journal of Social Sciences 3(3-2), 1-20.

Mazuru, M. \& Nyambi, O., 2012, 'Africana motherhood: The Shona proverb and the familial and social roles of mothers as first teachers, cultural bearers and copartners', International Journal of Asian Social Science 2(1), 596-601.

Mugumbate, J. \& Nyanguru, A., 2013, 'Exploring African philosophy: The value of ubuntu in social work', African Journal of Social Work 3(1), 82-100.

Ogunsanya, K., n.d., 'Women and elections in African politics', viewed 15 February 2015, from http://www.mercury.ethz.ch/serviceengine/Files/... singledocument/.../Chapter3.pdf

Pearce, C., 1990, 'Tsika, hunhu and the moral education of primary school children', Zambezia XVII(ii), 145-160.

Thomas, L., 1997, 'Christinah Nku: A woman at the center of healing her nation', in E. Townesm (ed.), Embracing the spirit: Womanist perspectives on hope, salvation and transformation, Orbis Books, New York.

Uchem, R., 2003, 'Overcoming women's subordination in the Igbo African culture and in the Catholic Church', Annual Journal of Women and Women International 1(1), 20-25.

Van Stam, G., n.d., 'Ubuntu and peace: Without a mother, there is no home', viewed 15 February 2015, from http://www.academia.edu/8811815/Ubuntu_and Peace_Without_a_Mother_there_is_no_Home 